\title{
Erratum to: Suppression of isotope scrambling in cell-free protein synthesis by broadband inhibition of PLP enymes for selective ${ }^{15} \mathrm{~N}$-labelling and production of perdeuterated proteins in $\mathrm{H}_{2} \mathrm{O}$
}

\author{
Xun-Cheng Su $\cdot$ Choy-Theng Loh $\cdot$ Ruhu Qi • \\ Gottfried Otting
}

Published online: 17 September 2011

(C) Springer Science+Business Media B.V. 2011

Erratum to: J Biomol NMR (2011) 50:35-42

DOI 10.1007/s10858-011-9477-5

Due to an omission, the link to the electronic supplementary material (ESM) was not included in the original article. Please see below for this link.

The online version of the original article can be found under doi:10.1007/s10858-011-9477-5.

Electronic supplementary material The online version of this article (doi:10.1007/s10858-011-9562-9) contains supplementary material, which is available to authorized users.

X.-C. Su · C.-T. Loh · R. Qi · G. Otting ( $\bowtie)$

Research School of Chemistry, Australian National University,

Canberra, ACT 0200, Australia

e-mail: gottfried.otting@anu.edu.au

X.-C. Su

State Key Laboratory of Elemento-Organic Chemistry,

Nankai University, 300071 Tianjin, China 